\title{
Review: Hidrolisis Lignoselulosa dari Agricultural Waste Sebagai Optimasi Produksi Fermentable Sugar
}

\author{
Sutini $^{1, \mathrm{a}}$, Yohanita Restu Widihastuty ${ }^{1, \mathrm{~b}}$, Aida Nur Ramadhani ${ }^{1, \mathrm{c}^{*}}$ \\ ${ }^{1}$ Program Studi Teknik Kimia, Fakultas Teknik, Universitas Sebelas Maret, Jl. Ir. Sutami 36A Jebres, Surakarta \\ 57126. \\ E-mail: ahitmeup.mbaktini@gmail.com, byohanitarestu@gmail.com, c, ${ }^{*}$ aidaramadhani@staff.uns.ac.id
}

\begin{abstract}
Agricultural waste are produced from the agricultural sector, such as straw waste, bagasse, and palm fronds. Agricultural waste contains lignocellulose. Lignocellulose is a component consisting of cellulose, hemicellulose, and lignin. The content of cellulose can be used in various products, but the content of lignin and hemicellulose can inhibit the hydrolysis of lignocellulose. Cellulose has many uses such as propellant or explosive raw materials, and derivatives of alpha-cellulose can be processed into the production of bioethanol, glutamic acid, and biosolvent alcohol. The lignocellulose hydrolysis method greatly affects the levels of fermentable sugar produced. Research have been made to increase the hydrolysis of lignocellulose. In this paper, several methods can be used to increase the yield of fermentable sugar through the hydrolysis of lignocellulose, including pretreatment, delignification, hydrolysis, and saccharification methods. Pretreatment using $2 \%$ alkaline, thermal delignification, hydrolysis using xylanase and cellulase enzymes together can significantly increase the ability of lignocellulose hydrolysis to obtain optimal fermentable sugar yield. Simultaneous saccharification and hydrolysis are effective in increasing yield and product formation rate.
\end{abstract}

Keywords: Agricultural Waste, Lignocellulose, Cellulose, Pretreatment, Delignification, Saccharification, Hydrolysis, Xylanase, Cellulase, Fermentable Sugar

EQUILIBRIUM Volume 3 No.2 December 2019

Online at http:/ / equilibrium.ft.uns.ac.id 


\section{Pendahuluan}

Indonesia merupakan negara agraris yang memiliki sumber daya alam yang melimpah dan berbasis pada sektor pertanian. Banyaknya lahan pertanian di Indonesia dan semakin berkembangnya sektor pertanian tentunya berdampak semakin banyak pula limbah yang dihasilkan dari sektor pertanian. Sampai saat ini masih banyak limbah buangan yang belum tertangani dengan baik dan tepat. Limbah padat masih terlihat terbengkalai dimana-mana dan menimbulkan bau yang tidak sedap serta merusak pandangan mata.

Limbah pertanian mengandung banyak bahan lignoselulosa yang bisa didegradasi oleh enzim secara bioproses. Bahan lignoselulosa dengan komponen terbesar adalah selulosa (35-50\%), hemiselulosa (20-35\%) dan lignin (10-25\%)[1]. Komponen ini merupakan sumber utama untuk menghasilkan produk bernilai seperti gula dari hasil fermentasi, bahan kimia, bahan bakar cair, sumber karbon, dan energi.

Lignoselulosa merupakan komponen polisakarida yang terdiri atas tiga tipe polimer yaitu selulosa, hemiselulosa, dan lignin. Selulosa merupakan salah satu polimer dengan pemanfaatan yang masih sangat terbatas. Selulosa hampir tidak pernah ditemui dalam keadaan murni di alam, melainkan selalu berikatan dengan bahan lain seperti lignin dan hemiselulosa. Adanya lignin serta hemiselulosa di sekeliling selulosa merupakan hambatan utama untuk menghidrolisis selulosa [2].

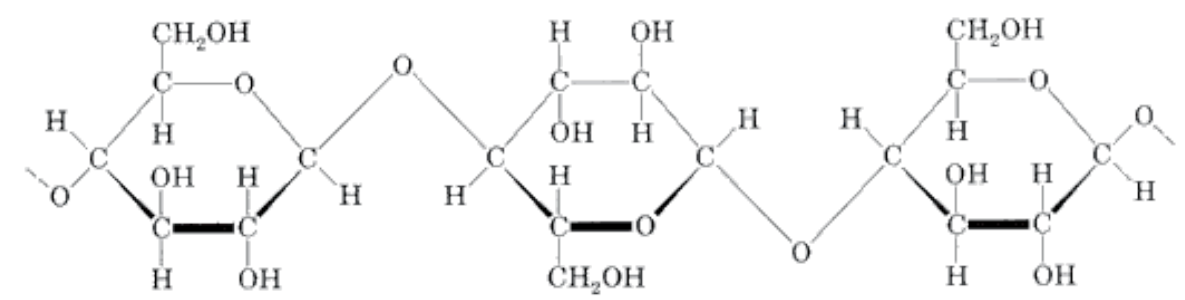

Gambar 1. Struktur Kimia Selulosa

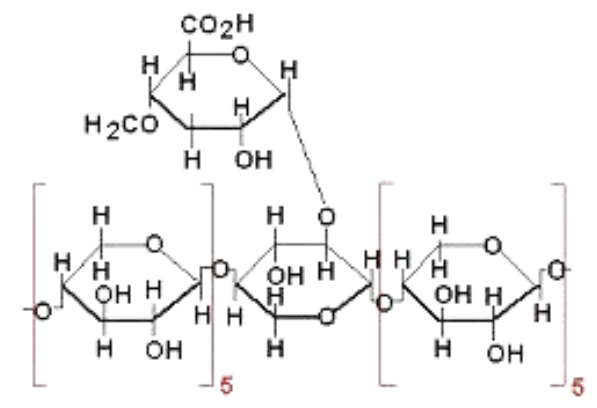

Gambar 2. Struktur Kimia Hemiselulosa

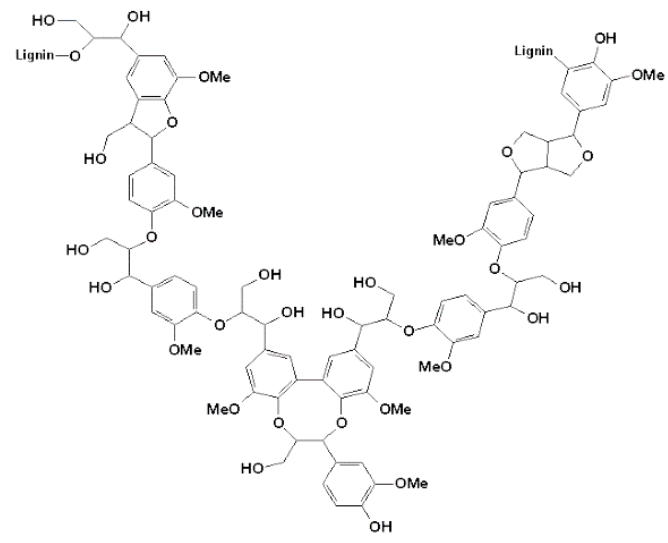

Gambar 3. Struktur Kimia Lignin 
Selulosa merupakan polimer glukosa dengan ikatan $\beta-1,4$ glukosida dalam rantai lurus. Bangun dasar selulosa berupa suatu selobiosa yaitu dimer dari glukosa. Rantai panjang selulosa terhubung secara bersama melalui ikatan hidrogen dan gaya van der waals [3]. Hidrolisis sempurna selulosa akan menghasilkan monomer selulosa yaitu glukosa, selanjutnya glukosa yang dihasilkan dapat difermentasi menjadi menjadi produk, sedangkan hidrolisis tidak sempurna akan menghasilkan disakarida dari selulosa yaitu selobiosa [4].

Limbah pertanian banyak mengandung lignoselulosa. Jerami, ampas tebu, pelepah sawit merupakan limbah lignoselulosa yang masih mempunyai nilai ekonomis bila dilakukan pengolahan lebih lanjut. Sejalan dengan perkembangan bioteknologi, pemanfaatan mikroba dalam proses biokonversi limbah dapat dilakukan guna mendapatkan nilai tambah dari bahan limbah tersebut menjadi produk lain seperti pupuk, bioetanol, pakan ternak dan sebagainya. Pada umumnya, limbah pertanian mengandung bahan lignoselulosa yang merupakan komponen utama dari tanaman. Penggunaan bahan lignoselulosa lebih menarik dibandingkan dengan bahan berpati karena tidak bersaing dalam penggunaan untuk kepentingan pangan [5].

Dalam paper ini akan dikaji beberapa metode yang dapat digunakan dalam proses hidrolisis lignoselulosa, diantaranya metode pretreatment, delignifikasi, hidrolisis dan sakarifkasi. Selanjutnya akan dijelaskan juga mengenai aplikasi gula reduksi hasil dari hidrolisis enzimatis secara detail.

\section{Metodologi Penelitian}

Metode sintesis lignoselulosa meliputi metode pretreatment, delignifikasi, hidrolisis, dan sakarifikasi. Adapun tulisan ini membahas tentang berbagai metode untuk produksi fermentable sugar.

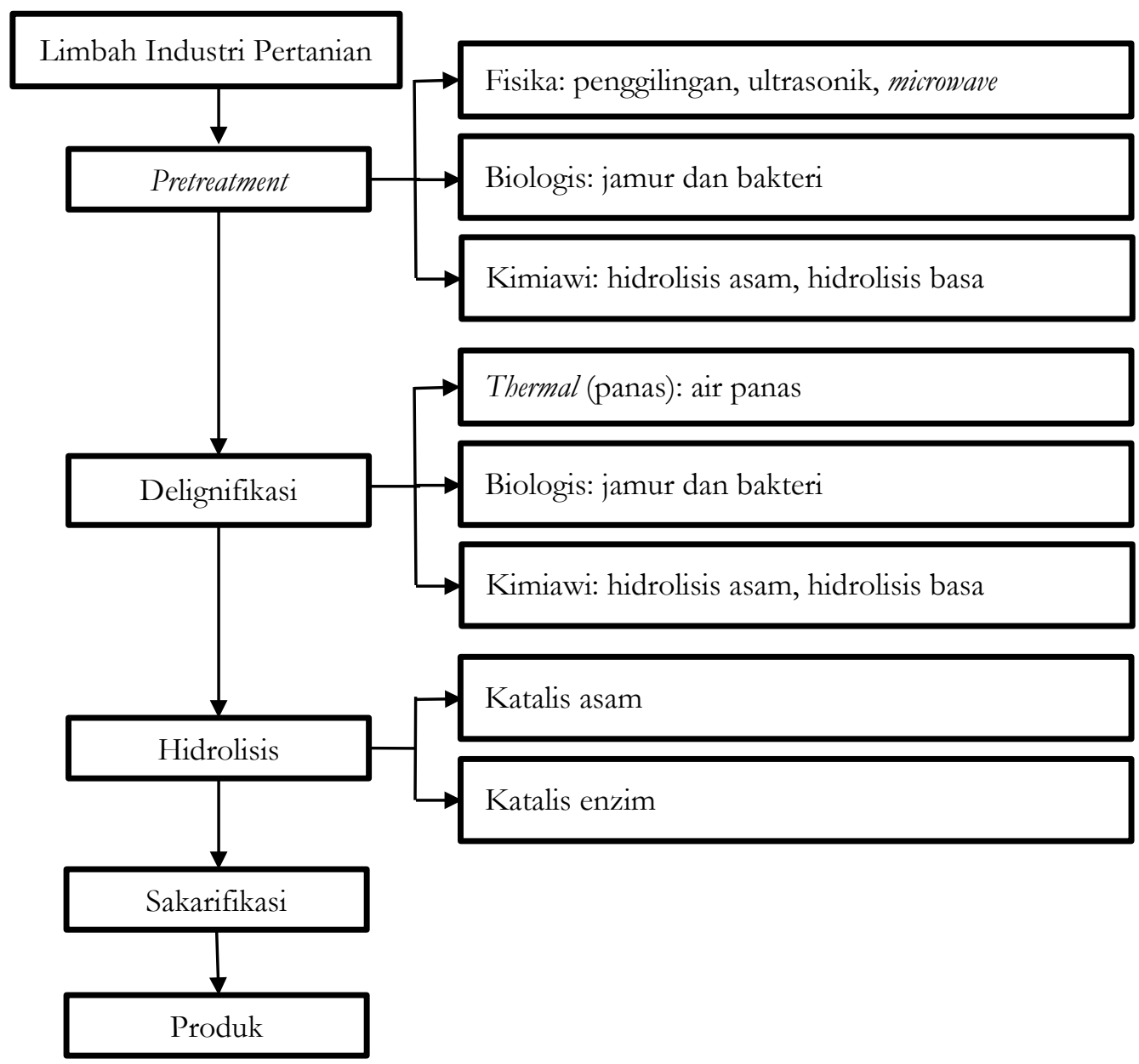

Gambar 4. Metode Produksi Fermentable Sugar

Review: Hidrolisis Lignoselulosa dari Agricultural Waste Sebagai Optimasi Produksi 


\subsection{Metode Pretreatment}

Limbah pertanian mengandung banyak lignoselulosa dimana di dalamnya terdapat selolusa yang dapat dihidrolisis secara enzimatis menjadi gula reduksi atau fermentable sugar. Limbah pertanian tersebut contohnya:
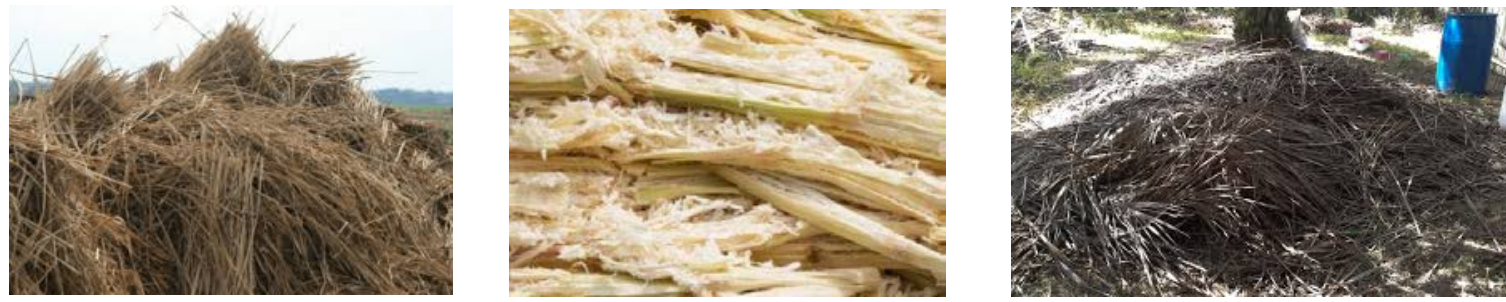

Gambar 5 (a). Limbah jerami Gambar 5 (b). Limbah ampas tebu Gambar 5 (c). Limbah pelepah sawit

Tabel 1. Kandungan Selulosa, Hemiselulosa, dan Lignin dalam Berbagai Agricultural Waste

\begin{tabular}{ccccc}
\hline Limbah & \multicolumn{3}{c}{ Kandungan } & \multirow{2}{*}{ Referensi } \\
\cline { 2 - 4 } Pertanian & \% Selulosa & \% Hemiselulosa & \% Lignin & \\
\hline Jerami & 37,71 & 21,99 & 16,62 & {$[6]$} \\
& 37,71 & 21,99 & 16,62 & {$[7]$} \\
Ampas tebu & $35-50$ & $20-35$ & $10-25$ & {$[1]$} \\
& 52,7 & 20,00 & 24,20 & {$[8]$} \\
& $40-50$ & $23-45$ & $18-24$ & {$[9]$} \\
Pelepah sawit & $40-50$ & $25-35$ & $15-35$ & {$[10]$} \\
& 52,42 & 25,80 & 21,69 & {$[11]$} \\
& 34,89 & 27,14 & 19,87 & {$[12]$} \\
& 21,12 & 27,94 & 16,94 & {$[13]$} \\
\hline
\end{tabular}

Perlakuan awal (pretreatment) merupakan tahapan proses yang bertujuan untuk memecah struktur kristal lignin-selulosa dan membuang lignin sehingga enzim selulase dapat bersinggungan langsung dengan selulosa. Pretreatment merupakan salah satu proses terpenting dalam biokonversi substrat berlignoselulosa. Proses pretreatment dibutuhkan untuk memutuskan ikatan lignin dari struktur lignoselulosa serta mengurangi derajat polimerisasi dan sifat kristalin selulosa. Proses pretreatment akan meningkatkan efisiensi proses hidrolisis dengan cara memperluas permukaan kontak substrat dengan enzim [15]. Namun demikian, pemilihan metode pada proses pretreatment akan mempengaruhi proses selanjutnya seperti hidrolisis dan fermentasi. Kondisi yang tidak diinginkan selama proses pretreatment akan membuat terbentuknya produk parsial hemiselulosa dan lignin serta senyawa toksik atau inhibitor yang akan mengurangi kinerja enzim maupun mikroba. Metode pretreatment tersebut memiliki kelebihan dan kekurangan masing-masing dan aplikasinya juga akan bergantung pada bahan lignoselulosa yang digunakan. Oleh karena itu, metode pretreatment perlu dipertimbangkan terlebih dahulu supaya proses konversi dapat berjalan optimal. Jenis pretreatment bahan baku yang biasanya dilakukan meliputi cara mekanik, kimiawi, dan biologis.

Tabel 2 Metode Pretreatment Hidrolisis Lignoselulosa

\begin{tabular}{|c|c|c|c|c|c|}
\hline Cara & Proses & Contoh & Suhu & $\begin{array}{l}\text { Pengura } \\
\text { ngan } \\
\text { Lignin }\end{array}$ & Referensi \\
\hline Fisika & Pembakaran menjadi abu & $\begin{array}{l}\text { Pembuatan } \\
\text { ekstrak abu dari } \\
\text { pembakaran } \\
\text { Tandan Kosong } \\
\text { Sawit (TKS) }\end{array}$ & $*$ & $*$ & [12] \\
\hline
\end{tabular}




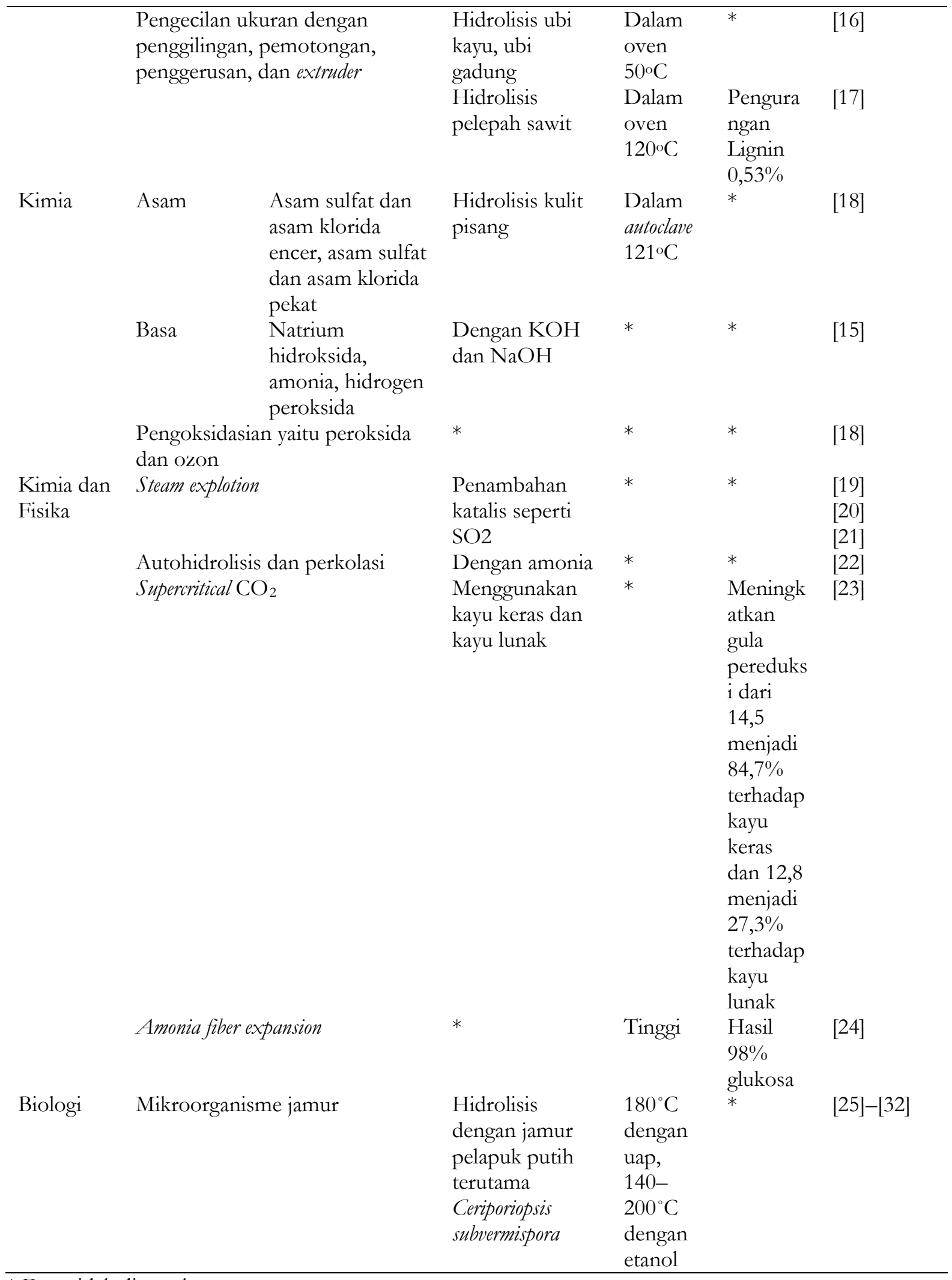

* Data tidak ditemukan 


\subsubsection{Cara mekanik}

Caesari, dkk [12] melakukan percobaan menggunakan metode mekanik dengan pembakaran tandan kosong sawit dalam incenerator yang menghasilkan ekstrak abu kelapa sawit kemudian disaring, ditambahkan air, dan diaduk sebelum didiamkan. Larutan hasil ekstrak diperoleh dengan memisahkan endapan abu dari larutan, kemudian larutan tersebut disiapkan sebagai larutan pemasak dan dilakukan uji $\mathrm{pH}$.

Hartiarti [16] melakukan percobaan dengan pengecilan ukuran melalui diparut/digerus/digiling dan dihancurkan dengan blender dan ditambahkan air.. Bubur pati kemudian disaring dengan menggunakan kain saring guna memisahkan ampasnya. Filtrat hasil penyaringan kemudian diendapkan. Endapan yang terbentuk kemudian dipisahkan dengan cara membuang airnya dan di oven. Pati yang diperoleh selanjutnya dikarakterisasi dengan analisa proksimat.

\subsubsection{Cara biologis}

Hermiati [33] melakukan percobaan dengan menggunakan perlakuan secara biologis menggunakan mikroorganisme jamur pelapuk coklat, jamur pelapuk putih, dan jamur pelunak untuk mendegradasi lignin dan hemiselulosa yang ada dalam bahan lignoselulosa. Di antara ketiga jamur tersebut, yang paling efektif untuk perlakuan pendahuluan pada bahan lignoselulosa adalah jamur pelapuk putih (white-rot fungi).

\subsubsection{Cara kimiawi}

Seftian [18] melakukan percobaan dengan menggunakan bahan kimia seperti asam, alkali, dan pengoksidasian yaitu peroksida dan ozon. Diantara metode ini, pretreatment asam encer menggunakan $\mathrm{H}_{2} \mathrm{SO}_{4}$ adalah metode yang paling banyak digunakan. Tergantung pada jenis bahan kimia yang digunakan, pretreatment bisa memiliki dampak yang berbeda pada komponen struktural lignoselulosa. Alkaline pretreatment, ozonolysis, peroksida dan oksidasi pretreatment lebih bisa efektif dalam penghapusan lignin sedangkan pretreatment asam encer lebih efisien dalam solubilisasi hemiselulosa [34].

Ramly et al [15] menunjukkan bahwa metode pretreatment menggunakan basa akan meningkatkan efektifitas proses hidrolisis enzimatis dengan cara meningkatkan aksesibilitas enzim pada permukaan selulosa. Hasil penelitian tersebut diketahui bahwa pretreatment secara basa menggunakan $2 \%(\mathrm{~b} / \mathrm{v}) \mathrm{KOH}$ atau $\mathrm{NaOH}$ dan dikombinasikan dengan perlakuan panas pada suhu $121^{\circ} \mathrm{C}$ dan 15 psi akan meningkatkan 58,5-64,5\% laju konversi terbentuknya gula reduksi dibandingkan dengan jerami padi tanpa pretreatment. Hal ini menunjukkan bahwa pretreatment secara basa dapat efektif digunakan untuk proses biokonversi jerami padi.

Metode lain dilaporkan seperti steam explotion pretreatment terhadap komponen kayu yang keras [21] serta metoda autobydrolysis dan perkolasi dengan amonia untuk menghilangkan lignin dan mendapatkan hemiselulosa [22]. Selain itu, metode dengan menggunakan supercritical $\mathrm{CO}_{2}$ dapat membantu proses hidrolisis dari selulosa sehingga dapat meningkatkan gula pereduksi dari 14,5 menjadi $84,7 \%$ terhadap kayu keras dan 12,8 menjadi 27,3\% terhadap kayu lunak [23]. Metoda ammonia fiber expansion (AFEX) merupakan gabungan antara proses fisika (temperatur tinggi dan tekanan) serta proses kimia (amonia) untuk mendapatkan hasil yang efektif dan dari perlakuan ini dapat diperoleh kurang lebih $98 \%$ glukosa [24].

\subsection{Metode Delignifikasi}

Delignifikasi adalah suatu proses mengubah struktur kimia biomassa berlignoselulosa dengan tujuan mendegradasi lignin secara selektif sehingga menguraikan ikatan kimianya baik secara ikatan kovalen, ikatan hidrogen maupun ikatan van der waalls, dengan komponen kimia lain pada bahan berlignoselulosa [35]. Proses delignifikasi akan melarutkan kandungan lignin di dalam bahan sehingga mempermudah proses pemisahan lignin dengan serat. Delignifikasi dapat dilakukan melalui proses fisika (thermal), kimia, maupun biologi.

Zulfieni [36] melakukan proses delignifikasi pelepah sawit untuk mendapatkan selulosa yang memiliki kadar lignin rendah melalui proses thermal. Proses delignifikasi dilakukan setelah proses hidrolisis. Hasil hidrolisis disaring dan dicuci dengan air panas untuk menghilangkan lindi hitam. Residu ditambahkan dengan larutan pemasak ekstrak abu TKS yang baru dengan nisbah padatan larutan 1:5, kondisi delignifikasi pada temperatur $100^{\circ} \mathrm{C}$ dan waktu 30 menit. Selanjutnya residu dicuci hingga $\mathrm{pH}$ netral. 
Kurniati [37] melakukan proses secara kimia dengan penambahan basa $\mathrm{NaOH} 6 \%$ dengan perbandingan sebesar 1:5. Sampel yang telah direndam selama 90 menit kemudian disaring dan diambil padatannya saja, setelah itu di cuci menggunakan akuades hingga pH mencapai netral. Sampel yang sudah dicuci, dikeringkan menggunakan oven dan diayak dengan ukuran sekitar 80 mesh. Penurunan lignin dalam bahan melalui proses thermal mampu mencapai $6 \%$ dari persen kandungan lignin mula-mula yang terkandung dalam bahan. Selain dengan basa proses delignifikasi secara kimia dapat dilakukan dengan larutan asam yaitu $\mathrm{H}_{2} \mathrm{SO}_{4} \quad 0,5 \%$ dengan waktu pemanasan 30 menit terjadi penurunan kadar lignin sebesar $8 \%$.

\subsection{Metode Hidrolisis dan Sakarifikasi}

Hidrolisis merupakan suatu reaksi pemecahan molekul besar menjadi bagian-bagian yang lebih kecil yang merupakan komponen monomer dari senyawa itu sendiri melalui adisi oleh air. Pemutusan rantai polimer tersebut dapat dilakukan dengan dua metode, yaitu secara enzimatis dan kimiawi. Hidrolisis kimiawi biasanya menggunakan asam sulfat $\left(\mathrm{H}_{2} \mathrm{SO}_{4}\right)$ atau asam klorida $(\mathrm{HCl})$, sedangkan hidrolisis enzimatis adalah hidrolisis dengan menggunakan enzim. [38]

Tabel 3. Hidrolisis dengan Katalis Asam

\begin{tabular}{lllllll}
\hline Bahan & Waktu & Tekanan $(\mathrm{atm})$ & Suhu $\left({ }^{\circ} \mathrm{C}\right)$ & $\mathrm{pH}$ & \% Glukosa & Referensi \\
\hline Jerami Padi & 2 hari & 1 & 30 & 3 & 40,33 & {$[39]$} \\
Ampas tebu & 15 menit & 1 & 121 & 1 & 4,2 & {$[40]$} \\
Pelepah sawit & 100 menit & 1 & 121 & 1 & 19,49 & {$[17]$} \\
\hline
\end{tabular}

Tabel 4. Hidrolisis dengan Katalis Enzim

\begin{tabular}{lllllll}
\hline Bahan & Waktu & Tekanan $(\mathrm{atm})$ & Suhu $\left({ }^{\circ} \mathrm{C}\right)$ & $\mathrm{pH}$ & \% Glukosa & Referensi \\
\hline Jerami padi & 64 jam & 1 & 50 & 5 & 17,35 & {$[41]$} \\
Ampas tebu & 15 hari & 1 & 50 & 5 & 13,442 & {$[42]$} \\
Pelepah sawit & 124 jam & 1 & 60 & $5-6$ & 18,7 & {$[43]$} \\
\hline
\end{tabular}

Sakarifikasi adalah proses lanjutan dari hidrolisis untuk menghasilkan glukosa yang nantinya siap untuk dikonversi menjadi produk dengan fermentasi menggunakan yeast/ragi/khamir. Monosakarida hasil sakarifikasi bergantung pada seberapa maksimal dari proses-proses sebelumnya, yang artinya proses-proses tersebut akan menentukan besarnya produk akhir fermentasi.

Salah satu potensi dari fermentable sugar adalah dengan mengubahnya menjadi bioenergi contohnya bioetanol. Khamir yang digunakan adalah Saccharomyces cerevisiae, spesies khamir yang memiliki daya konversi gula menjadi etanol sangat tinggi. Saccharomyces cerevisiae memerlukan suhu $30^{\circ} \mathrm{C}$ dan $\mathrm{pH}$ 4,0-5,5 agar dapat tumbuh dengan baik. (15)

Tabel 5. Proses Fermentasi Beberapa Agricultural Waste

\begin{tabular}{llllllll}
\hline Bahan & Waktu & Tekanan $(\mathbf{a t m})$ & Suhu $\left({ }^{\circ} \mathbf{C}\right)$ & pH & \% Etanol & \% Yield & Referensi \\
\hline Jerami Padi & 7 hari & 1 & 30 & 4,5 & 12,89 & $*$ & {$[39]$} \\
Ampas Tebu & 72 jam & 1 & 38 & 4,5 & 22,64 & 29,18 & {$[44]$} \\
& 3 hari & 1 & $28-30$ & 5 & 39,571 & $*$ & {$[43]$} \\
Pelepah sawit & 48 jam & 1 & 32 & 4 & 4 & 9,6 & {$[17]$} \\
& 24 jam & 1 & 32 & 4 & 4,3699 & $*$ & {$[45]$} \\
\hline
\end{tabular}

* Data tidak ditemukan

\section{Aplikasi}

Fermentable sugar dapat diolah lebih lanjut menjadi produk baru melalui fermentasi dengan menggunakan berbagai macam mikroorganisme. Berikut contoh aplikasi pemanfaatan dari fermentable sugar:

Review: Hidrolisis Lignoselulosa dari Agricultural Waste Sebagai Optimasi Produksi 
Tabel 6. Aplikasi Pemanfaatan Fermentable Sugar

\begin{tabular}{|c|c|c|c|c|}
\hline Produk & & $\begin{array}{l}\text { Mikroorganisme } \\
\text { yang digunakan }\end{array}$ & Residu & Referensi \\
\hline \multirow[t]{9}{*}{ Bioproduk } & $\begin{array}{l}\text { Enzim Inulinase } \\
\text { max activity } 0,088\end{array}$ & $\begin{array}{l}\text { K. marxianus } \\
\text { NRRL } 7571\end{array}$ & \multirow[t]{6}{*}{ Ampas tebu } & \multirow[t]{16}{*}{ [46] } \\
\hline & $\mathrm{U} / \mathrm{gds}$ & & & \\
\hline & $\begin{array}{l}\text { Enzim Inulinase } \\
\text { max activity } 1,77\end{array}$ & A. parasiticus & & \\
\hline & $\mathrm{U} / \mathrm{gds}$ & & & \\
\hline & Enzim alkaline & B. alcalophilus & & \\
\hline & $\begin{array}{l}\text { protease } \max \\
\text { activity } 510 \mathrm{U} / \mathrm{mL}\end{array}$ & LW8 & & \\
\hline & $\begin{array}{l}\text { Enzim } \\
\text { endoglukanase }\end{array}$ & A. Niger 38 & Jerami & \\
\hline & max activity 9,3 & & & \\
\hline & $\mathrm{U} / \mathrm{mL}$ & & & \\
\hline Biopolimer & $\begin{array}{l}\text { Poly-3- } \\
\text { hydroxybutvrate }\end{array}$ & $\begin{array}{l}\text { Cupriavidus } \\
\text { necator }\end{array}$ & Kelapa sawit & \\
\hline \multirow[t]{2}{*}{ Biosolven } & ABE butanol & $\begin{array}{l}\text { C. acetobutylicum } \\
\text { B5313 }\end{array}$ & \multirow[t]{2}{*}{ Ampas tebu } & \\
\hline & ABE etanol & $\begin{array}{l}\text { C. acetobutylicum } \\
\text { B5313 }\end{array}$ & & \\
\hline Biosurfaktan & Rhamnolipids & $\begin{array}{l}\text { Pseudomonas } \\
\text { aeruginosa PAO1 }\end{array}$ & Kelapa sawit & \\
\hline \multirow[t]{3}{*}{ Asam organik } & Asam laktat & Lactococus lactis & \multirow[t]{2}{*}{ Ampas tebu } & \\
\hline & & $\begin{array}{l}\text { IO-1 } \\
\text { B }\end{array}$ & & \\
\hline & Asam oksalat & $\begin{array}{l}\text { Phanerochaete } \\
\text { chrysosporium }\end{array}$ & Jerami & \\
\hline
\end{tabular}

\section{Kesimpulan dan Saran}

Banyak limbah agrikultural yang dapat diolah menjadi gula pereduksi. Gula pereduksi (fermentable sugar) jika diteruskan lebih lanjut akan menghasilkan produk-produk yang berguna seperti bioproduct, biosolvent, asam organik, biosurfaktan dan biopolimer.

Pemilihan metode pada proses pretreatment akan mempengaruhi proses selanjutnya seperti hidrolisis dan fermentasi. Kondisi yang tidak diinginkan selama proses pretreatment akan membuat terbentuknya produk parsial hemiselulosa dan lignin serta senyawa toksik atau inhibitor yang akan mengurangi kinerja enzim maupun mikroba.

Perlu penelitian lebih lanjut untuk limbah agrikultural lain seperti bonggol jagung, kulit jagung, daun nanas, dan sebagainya.

\section{Referensi}

[1] B. C. Saha, "Lignocellulose Biodegradation and Application in Biotechnology," US Gov. Work. Am. Chem. Soc., vol. 2, no. 14, 2004.

[2] E. Sjostrom, Kimia Kayu: Dasar-dasar dan Penggunaan, 2nd ed. Yogyakarta: Universitas Gadjah Mada.

[3] J. M. Perez, J., J. M. Dorado, T. Rubia, "Biodegradation and Biological treatments of Cellulose, Hemicellulose and Lignin: An Overview," Int. Microbiol, vol. 5, pp. 53-63, 2002.

[4] L. T. Fan, Y. H. Lee, M. M. Gharpuray, "The Nature of Lignocellulosic and Their Pretreatment for Enzymatic Hydrolysis," Adv. Bichem. Eng., vol. 23, pp. 158-187, 1982.

[5] R.R. Singhania, "Cellulolytic Enzymes. Biotechnology for Agro-Industrial Residues Utilization,” vol. 
20, pp. 371-381, 2009.

[6] K. H. Dewi, and A. Agrosia "Hidrolisis Limbah Hasil Pertanian Secara Enzimatik," Akta Agrar., vol. 5, no. 2, pp. 67-71, 2002.

[7] R. Pratiwi, D. Rahayu, and M. I. Barliana, "Pemanfaatan Selulosa dari Limbah Jerami Padi (Oryza sativa) Sebagai Bahan Bioplastik," IJPST, vol. 3, no. 3, pp. 83-91, 2016.

[8] M. Samsuri et al., "Pemanfaatan Selulosa Bagas untuk Produksi Ethanol Melalui Sakarifikasi dan Fermentasi Serentak dengan Enzim Xylanase," Makara Teknol., vol. 11, no. 1, pp. 17-24, 2007.

[9] A. Mandal and D. Chakrabarty, "Isolation of Nanocellulose from Waste Sugarcane Bagasse (SCB) and Its Characterization," Carbohydr. Polym., vol. 86, pp. 1291-1299, 2011.

[10] Jufrinaldi, "Isolasi Selulosa dari Bagas Tebu Melalui Pemanasan Iradiasi Gelombang Mikro," J. Ilm. Tek. Kim. UNPAM, vol. 2, no. 2, pp. 36-46, 2018.

[11] M. Tewari, P. C. Singh, V.K., Gope, and A. K. Chaudhary, "Evaluation of Mechanical Properties of Bagasse-Glass Fiber Reinforced Composite," J. Mater. Environ. Sci., vol. 3, no. 1, pp. 187-194, 2012.

[12] Caesari, Padil, and Yelmida, "Pemurnian Selulosa Alfa Pelepah Sawit Menggunakan Enzim Xylanase," J. Tek. Kim. UR, vol. 1, no. 1, pp. 1-8, 2014

[13] A. Imsya and P. R, "Perubahan Kandungan Lignin, NDF, dan ADF Pelepah Sawit Melalui Proses Biodegumming sebagai Sumber Bahan Pakan Serat Ternak Ruminansia," J.I. Ternak dan Vet., vol. 14, no. 4, pp. 284-288, 2009.

[14] K. W. Law, W. Daud, and W.R, "Oil Palm Fibers as Papermaking Material: Potentials and Challenges," Bioresources, vol. 6, no. 1, pp. 901-917, 2011.

[15] N. A. M. Remli, U. K. M. Shah, R. Mohamad, and S. Abd-Aziz, "Effects of Chemical and Thermal Pretreatments on The Enzymatic Saccharification of Rice Straw for Sugars Production," Bioresources, vol. 9, no. 1, pp. 510-522, 2013.

[16] A. Hartiati, I. W. Gede, and S. Yoga, "Pemanfaatan Umbi Minor Gadung sebagai Bahan Baku Produksi Gula Cair Menggunakan Proses Likuifikasi dan Sakarifikasi Secara Enzimatis," in Seminar Agroindustri dan Lokakarya Nasional FKPT-TPI, 2015, pp. 147-154.

[17] N. M. Rilek, N. Hidayat, and Y. Sugiarto, "Hidrolisis Lignoselulosa Hasil Pretreatment Pelepah Sawit (Elaeis guineensis Jacq) menggunakan H2SO4 pada Produksi Bioetanol," J. Teknol. dan Manaj. Agroindustri, vol. 6, no. 2, pp. 76-82, 2017.

[18] D. Seftian, F. Antonius, and M. Faizal, "Pembuatan Etanol dari Kulit Pisang Menggunakan Metode Hidrolisis Enzimatik dan Fermentasi," J. Tek. Kim., vol. 18, no. 1, pp. 10-16, 2012.

[19] Hahn-Hagerdal, B. Galbe, G. M.F.M. Gorwa-Grauslund. Liden, and G. Zacchi, "Bio-ethanol-the Fuel of Tomorrow from the Residues of Today," Sci. Direct, Elseveir, 2006.

[20] Hamelinck, V. Hooijdonk, and Faaij, "Ethanol from lignocellulosic biomass: Techno-economic performance inshort-, midle- and long-term," Biomass and Bioenergy, vol. 28, pp. 384-410, 2005.

[21] K. Shimizu, K. Sudo, H. Ono, M. Ishihara, T. Fujii, and S. Hishiyama, "Integrated Process for Total Utilization of Wood Componen by Steam Explosion Pretreatment," Biomass and Bioenergy, vol. 14, no. 3, pp. 195-203, 1998.

[22] H. H. Yoon, "Pretreatment of Lignocellulosic Biomass by Autohydrolysis and Aqueous Ammonia Percolation," Korean J. Chem. Eng., vol. 15, no. 6, pp. 631-636, 1998.

[23] K. H. Kim and J. Hong, "Supercritical CO2 Pretreatment of Lignocellulose Enhances Enzymatic Cellulose Hydrolysis," Bioresour. Technol., vol. 77, no. 139-144, 2001.

[24] V. Balan, B. B, and S. P. . Chundawat, "Lignocellulose Biomass treatment Using AFEX," Method Mol. Biol., vol. 581, pp. 61-77, 2009.

[25] Syafwina, E. D. Wong, Y. Honda, T. Watanabe, and M. Kuwahara, "Pretreatment of empty fruit bunch of oil palm by white-rot fungi for the utilization of its component," Wood Res, pp. 351-356, 2002.

[26] Syafwina, H. Y, T. Watanabe, and M. Kuwahara, "Pretreatment of oil palm empty fruit bunch by white-rot fungi for enzymatic saccharification," Wood Res, vol. 89, pp. 19-20, 2002.

[27] H. Itoh, M. Wada, Y. Honda, M. Kuwahara, and T. Watanabe, "Bioorganosolve pretreatments for simultaneous saccharification and fermentation of beech wood by ethanolysis and white rot fungi," $J$. Biotechnol., vol. 103, pp. 273-280, 2003.

[28] Syafwina, T. Watanabe, Y. Honda, M. Kuwahara, and T. Watanabe, "Simultaneous Saccharification and Fermentation of Oil Palm Empty Fruit Bunch Pretreated by White Rot Fungi for Ethanol Production," Wood Res, pp. 313-316, 2004.

Review: Hidrolisis Lignoselulosa dari Agricultural Waste Sebagai Optimasi Produksi 
[29] M. Samsuri, M. Gozan, R. Mardias, M. Baiquni, H. Hermansyah, A. Wijanarko, B. Prasetya, M. Nasikin, "Pemanfaatan Selulosa Bagas untuk Produksi Etanol Melalui Sakarifikasi dan Fermentasi Serentak dengan Enzim Xylanase," J. Tek. Kim. UI, vol. 11, no. 1, pp. 17-24, 2007.

[30] T. Tanabe, Y. Baba, N. Shinohara, T. Mitani, Y. Honda, and T. Watanabe, "Pretreatments of Softwood by Microwave Irradiation and White Rot Fungi for Ethanol Production,” p. 379, 2004.

[31] S. Hatakeyama and M. Kuwahara, "Degradation of Discharged Stump and Root of Japanese Cedar by Wood Rotting Basidiomycetes," p. 373, 2004.

[32] M. Samsuri, B. Prasetya, E. Hermiati, T. Idiyanti, K. Okano, Syafwina, Y. Honda, and T. Watanabe, "Pretreatments for Ethanol Production from Bagasse by Simultaneous Saccharification and Fermentation," pp. 288-294, 2005.

[33] E. Hermiati, D. Mangunwidjaja, T. C. Sunarti, and O. Suparno, "Pemanfaatan Biomassa Lignoselulosa Ampas tebu untuk Produksi Bioetanol," J. Litbang Pertan., vol. 29, no. 4, pp. 121-130, 2010.

[34] Y. Sun and J. Cheng, "Hidrolysis of Lignocellulose Material for Ethanol Production: a Review," Bioresour. Technol., vol. 83, pp. 1-11, 2002.

[35] L. Agustini, L., dan Efiyanti, "Pengaruh Perlakuan Delignifikasi Terhadap Hidrolisis Selulosa dan Produksi Etanol Dari Limbah Berlignoselulosa," vol. 33, no. 1, pp. 69-88, 2015.

[36] W. Y. Zulfieni, "Hidrolisis Pelepah Sawit Untuk Memurnikan Selulosa- $\alpha$ Menggunakan Larutan Pemasak dan Ekstrak Abu TKS," Skripsi Universitas Indonesia, pp. 78, 2010.

[37] Y. Kurniati, S. Budijanto, L. Nuraida, F. Nur, and A. Dewi, "Peningkatan Senyawa Fenolik Bekatul dengan SSF (Solid State Fermentation) sebagai Pencegah Kanker," Iptek Tanam. Pangan, vol. 12, no. 2, pp. 97-104, 2017.

[38] T. M. Fenida, "Studi Reaksi Hidrolisis Glukosa untuk Menghasilkan Senyawa Asam Levulinat Menggunakan Katalis Homogen dan Katalis Heterogen Asam," Skripsi Universitas Indonesia, pp. 83, 2010.

[39] Y. Andayana, "Pembuatan Ethanol dari Jerami Padi dengan Proses Hidrolisis dan Fermentasi," Jur. Tek. Kim. Fak. Teknol. Ind. UPN “Veteran” Jatim, vol. 8, no. 2, pp. 54-57, 2014.

[40] Sutikno, Marniza, and N. Sari, "Pengaruh Perlakuan Awal Basa dan Hidrolisis Asam terhadap Kadar Gula Reduksi Ampas Tebu," J. Teknol. Ind. dan Has. Pertan., vol. 20, no. 2, pp. 65-72, 2015.

[41] H. Ferdiansyah, S. H. Sumarlan, and B. D. Argo, "Hidrolisis Enzimatik Menggunakan Enzim Selulase dari Trichoderma reseei dan Aspergillus niger pada Produksi Bioetanol Jerami Padi," J. Keteknikan Pertan. Trop. dan Biosistim, vol. 3, no. 2, pp. 211-216, 2015.

[42] E. Ella Saparianti, T. Dewanti, and S. K. Dhoni, "Hidrolisis Ampas Tebu Menjadi Glukosa Cair Oleh Kapang Trichoderma viride," J. Teknol. Pertan., vol. 5, no. 1, pp. 1-10, 1992.

[43] H. Sitompul, D. R. Putra, and P. N. F, "Pengaruh Waktu dan Konsentrasi Enzim Selulase pada Proses Hidrolisis Tandan Kosong Kelapa Sawit Menjadi Glukosa," Anal. Anal. Environ. Chem., vol. 1, no. 01, pp. 8-16, 2016.

[44] M. Oktaviani, T. Fajriutami, and E. Hermiati, "Produksi Etanol dari Ampas Tebu Terdelignifikasi Alkali melalui Proses Sakarifikasi dan Fermentasi Serentak," Prosiding Seniati, pp. 45-51, 2016.

[45] Kristina, E. R. Sari, and Novia, "Alkaline Pretreatment dan Proses Simultan Sakarifikasi-Fermentasi untuk Produksi Etanol dari Tandan Kosong Kelapa Sawit," J. Tek. Kim., vol. 18, no. 3, pp. 34-43, 2012.

[46] P. Gutierrez-macias, M. De Lourdes, H. De Jesus, and B. E. Barragan-huerta, "The Production of Biomaterials from Agro-industrial Waste," Fresenius Environ. Bullet, vol. 26, no. 6, pp. 4128-4152, 2017. 